\title{
Les données probantes et la santé publique dans le débat public
}

\section{Evidence and public health in the public debate}

\author{
Roxane Borgès Da Silva ${ }^{1,2}$ \\ Published online: 18 February 2021 \\ (C) The Canadian Public Health Association 2021
}

Jusqu'à récemment, la recherche et les chercheurs en santé attiraient peu l'attention des médias à moins de faire une découverte importante où d'avoir des résultats probants ou inédits. La santé publique, souvent traitée comme le parent pauvre de la santé, était un domaine de recherche en santé peu connu, et faisait piètre figure dans les médias. Mais la pandémie actuelle de COVID-19 a révélé l'importance de la santé publique et plusieurs chercheurs se sont positionnés en vulgarisateur des connaissances.

La santé publique constitue un domaine large avec une assise multidisciplinaire et dont les recherches ont des effets mesurables plus souvent à long terme qu'à court terme. Quand on met en place une intervention de santé publique, ce n'est qu'après plusieurs années que les effets sur la santé des populations sont mesurables. Ainsi la population, les médias et la décision publique avaient peu d'intérêt pour ce type de résultats de recherche. Les coupures budgétaires en santé publique lors de la dernière réforme du système de soins de santé québécois illustrent ce désintérêt général (Fiset-Laniel et al. 2020). Mais avec la pandémie, la santé publique a connu un intérêt inédit auprès de la population et des médias.

Dès les premiers cas de COVID-19, la population et les médias souhaitaient comprendre ce domaine jusqu'à présent peu connu. Les chercheurs en santé publique ont été très sollicités par les journalistes et se sont placés en vulgarisateurs de la santé publique, de l'épidémiologie et de l'impact de la pandémie sur le système de santé et de santé publique. Ils ont ainsi pu mettre au jour leurs résultats de recherche sur la santé des populations, l'organisation des services de santé et les soins

Roxane Borgès Da Silva

roxane.borges.da.silva@umontreal.ca

1 École de santé publique, Université de Montréal, Montréal, Québec, Canada

2 Centre de recherche en santé publique, Montréal, Québec, Canada aux ainés, les plus grandes victimes de ce virus. Les chercheurs ont également été invités comme experts à analyser les décisions politiques et les restrictions sanitaires associées à la pandémie. Ils ont été invités à faire des analyses comparées de la pandémie, des décisions politiques et de leurs effets entre les provinces et les pays. Les chercheurs en santé publique ont enfin reçu une oreille attentive des médias et de la population pour démystifier la recherche et les connaissances en santé publique. Nous avons ainsi pu montrer et expliquer au grand public que la recherche en santé publique n'est pas uniquement faite dans des laboratoires. Nous avons enfin pu rendre des comptes à la population et l'informer des résultats de nos recherches financées par des organismes publics. Des résultats qui se retrouvaient la plupart du temps dans des revues scientifiques sans diffusion plus générale et plus accessible.

Dans un esprit de science ouverte et dans un contexte de recherches largement financées par des organismes publics, il est important de faciliter l'accès à la science et d'en diffuser largement les résultats. La population doit avoir accès via les médias aux résultats de recherche en santé publique qui les concernent directement. L'amélioration des habitudes de vie et des comportements de santé, de même que de l'ensemble des conditions qui façonnent la santé au quotidien passe par une compréhension des résultats associés. Les experts en santé publique qui étaient jusqu'à présent une voix peu écoutée, ont obtenu toute la place pour expliquer les concepts de santé publique, les vulgariser et diffuser leurs résultats. La pandémie a ainsi été révélatrice des objets de recherche en santé publique.

S'exposer médiatiquement comporte plusieurs enjeux et défis. Dans les médias écrits, on peut s'inquiéter du fait que nos propos ne soient pas compris et mal rapportés par les journalistes avec toutes les nuances évoquées. Mon expérience des dix derniers mois a été très rassurante. J'ai été agréablement surprise de constater que la plupart des journalistes rapportent avec une très grande fidélité, les propos des experts sans les déformer ou les interpréter. Les entrevues 
en direct à la radio et à la télévision demandent une plus grande préparation et une bonne dose d'assurance. À titre d'expert dans notre domaine, ces entrevues reviennent à expliquer dans un langage vulgarisé les concepts que nous expliquons déjà à nos étudiants depuis de nombreuses années.

Un autre enjeu porte sur notre rôle d'expert. À titre de scientifique, il est important de garder une ligne de communication factuelle basée sur les données probantes. Les données probantes ont évolué très vite au cours de la pandémie. Ainsi les experts ont pu se contredire entre le début de la pandémie et aujourd'hui. De même, il pourrait être facile de tomber dans le domaine du jugement ou du politique quand on s'exprime dans les médias et particulièrement quand on est en direct. Notre rôle de chercheur demande à garder une réserve dans les entrevues faites avec notre chapeau d'expert sur un sujet de santé publique. Les journalistes ont également un rôle critique important à jouer avant de diffuser des résultats de recherche dans les médias. Ils doivent s'assurer que les méthodes sont robustes et adaptées pour définir une relation de cause à effet. Plusieurs études basées sur des devis observationnels et indiquant différents effets protecteurs à des aliments, des vitamines, des médicaments ou des modes de vie, sans preuve expérimentale, ont été largement véhiculées par les médias. Elles peuvent entrainer de la désinformation et modifier les comportements individuels et l'adhérence aux recommandations de santé publique. Souvent les informations publiées par les revues scientifiques nécessitent d'attendre d'autres publications corroborant la première pour solidifier les hypothèses proposées. Les experts peuvent être sollicités par les médias pour les informer du niveau de preuve scientifique atteint par chaque publication.

L'exposition médiatique amène également des contrecoups auxquels nous ne sommes pas forcément préparés. Dans un monde où les tenants des théories du complot tentent de se faire une place dans le débat public, beaucoup de chercheurs exposés ont reçu des menaces. Ne pas céder face à ces attaques est la solution à adopter pour continuer d'informer et de vulgariser.

La pandémie a mis au jour l'importance de la santé publique et de la recherche en santé publique. Il est fondamental que les voix des experts ne s'éteignent pas avec la disparition de la pandémie. Dans une démocratie ou le politique tient compte de différents éléments, tel que la santé publique, l'opinion publique, les aspects sociaux et économiques, pour décider ou légiférer, les experts en santé publique doivent continuer d'avoir une tribune pour présenter leurs recherches et leur avis d'expert basés sur les données probantes issues de leurs recherches. Profitons de cette ouverture médiatique et des relations que nous avons tissés avec les journalistes pour continuer de nous exprimer et sensibiliser la population sur cet élément critique de la vie en société. N'hésitons pas à répondre positivement aux demandes d'entrevues pour participer au débat et informer la décision et à les alerter lorsque nos données éclairent des enjeux de population.

\section{Invited Editorial}

Until recently, health research and researchers rarely attracted media attention unless groundbreaking discoveries or significant breakthroughs were made. Public health research, often regarded as a "poor cousin" in the health field, was an underrepresented area of research that received little media attention. However, the recent COVID-19 pandemic is shining a spotlight on the importance of public health and has turned some researchers into public health communicators for nonscientific audiences.

Public health is a vast field, encompassing many disciplines, and the measurable research impacts tend to be longterm. When a public health response is put in place, it may be several years before the impact on a population's health can be measured. For this reason, the public, mass media and public decision-makers have shown little interest in these findings. Budget cuts during Quebec's last health care system reform are evidence of this general disinterest (Fiset-Laniel et al. 2020). However, because of the pandemic, there is now unprecedented interest in public health from citizens and the media.

As COVID-19 cases started to appear, the public and the media began taking an interest in public health, a field which until now was not greatly understood. Journalists sought out public health researchers, who began helping people understand public health, epidemiology, the pandemic's impact on health care, and the public health system. Researchers now had the opportunity to expose their findings on population health, health services organizations and elder care - the elderly being the largest group affected by the virus. Researchers were also called in as experts to analyze pandemic-related policy decisions and health restrictions. They were asked to perform comparative analyses on the pandemic, political decisions and the impact among provinces and countries. Public health researchers were finally able to gain media and public attention and to help demystify public health findings and knowledge. They were able to show people how health research is not limited to laboratories, and to publicly report and explain how research is funded by public agencies. These findings are often published in scientific journals and do not have widespread public distribution.

In the spirit of open science and in a context where research is primarily funded by public agencies, it is important to facilitate scientific understanding and to disseminate our findings to a wider audience. People should have access, through the media, to public health research findings that directly impact their lives. Improving health habits and lifestyle behaviours and the many factors affecting our day-to-day health requires 
an understanding of these findings. Public health experts who, until now, rarely had a voice, are now at the forefront, and this enables them to explain, disseminate and share public health information. The pandemic has therefore been helpful in instructing people about public health research topics.

Talking to the media can generate issues and challenges. There is always a concern that print journalists may not understand our statements or that our words could be misconstrued due to nuances in the language. My experience over the last 10 months has been encouraging. I was pleasantly surprised to learn that most journalists report expert findings quite accurately, without distorting or reinterpreting them. Live radio and television interviews require greater preparation and a good deal of confidence. As experts in our field, the purpose of these interviews is to explain concepts using the same type of language that we have used with our students over the years.

There is another issue that concerns us as experts. As scientists, we must maintain a factual, evidence-based line of communication. The evidence has changed very quickly over the course of the pandemic. As a result, experts could have contradicted themselves between the start of the pandemic and now. As well, it is easy to pass judgement or enter into political arguments when speaking to the media, especially when doing a live interview. Our role as researchers and experts requires that we maintain a certain reserve when being interviewed about public health information. Journalists also play an important and critical role when releasing findings to the media. They must ensure that their practices are reliable and relevant enough to show a clear cause and effect relationship. Studies based on observation, with no empirical evidence, that imply that certain foods, vitamins, drugs or lifestyles can provide protection against the virus, have been widely circulated by the media. This can promote misinformation, change people's behaviours, or affect adherence to public health recommendations. Often, information published by scientific journals requires a waiting period so that other publications can corroborate the information and strengthen the hypotheses. The media may then call on experts to help them understand the level of scientific evidence each publication contains.

Media exposure can also bring about a backlash for which we are not necessarily prepared. In a world where conspiracy theorists are attempting to gain a foothold in the public debate, many public-facing researchers have received threats. The solution to this is to not give in to these attacks so that we can continue to inform and explain.

The pandemic has highlighted the importance of public health and public health research. We must not allow experts' voices to fade into the background once the pandemic ends. In a democracy where politics takes into account various factors, such as public health, public opinion and socio-economic considerations, when making decisions or legislating, public health experts must continue to have a forum to present their research and evidence-based expert findings. We can benefit from a more open media and our newfound relationship with journalists to continue communicating and creating public awareness of this vital element of community life. We should respond positively to interview requests so that we can be part of the debate and the decision-making process and sound the alert when our data bring population issues to light.

\section{Référence bibliographique/References}

Fiset-Laniel, J., Guyon, A., Perreault, R., \& Strumpf, E. (2020). Public health investments: neglect or wilful omission? Historical trends in Quebec and implications for Canada. Canadian Journal of Public Health, 111(3), 383-388.

Publisher's Note Springer Nature remains neutral with regard to jurisdictional claims in published maps and institutional affiliations. 